\title{
DISTRIBUTED ECONOMIES THROUGH OPEN DESIGN AND DIGITAL MANUFACTURING
}

\section{ECONOMIAS DISTRIBUÍDAS POR MEIO DO OPEN DESIGN E DA FABRICAÇÃO DIGITAL}

\section{Iana Uliana Perez (UFPR) \\ Aguinaldo dos Santos, Dr. (UFPR)}

\author{
Key Words \\ Clothing Sector; Design for Sustainability; Fashion Design
}

\section{Palavras Chave}

Setor de Vestuário; Design para Sustentabilidade; Design de Moda

\begin{abstract}
The purpose of this paper is 1) to analyze the potential digital manufacturing technologies and open design have to achieve a distributed economy and 2) to identify the limits and possibilities of digital manufacturing and open design in relation to the principles of Design for Sustainability applied to the clothing sector. The method used was bibliographic review. This paper emphasizes the benefits of distributed economies on attending design for sustainability principles. Then, it discusses the relation between open design and digital manufacturing with distributed economies. We argue that open design and digital manufacturing have the potential to reduce the impacts caused by the clothing sector, but we emphasize that both strategies per se do not lead to a more sustainable scenario.
\end{abstract}

\section{RESUMO}

O objetivo deste artigo é 1) analisar o potencial das tecnologias de fabricação digital e do open design para alcançar uma economia distribuída e 2) identificar os limites e as possibilidades da fabricação digital e do open design em relação aos princípios de Design para Sustentabilidade aplicados ao setor de vestuário. O método utilizado foi a revisão bibliográfica. Este artigo enfatiza os benefícios das economias distribuídas no atendimento dos princípios do Design para Sustentabilidade. Em seguida, discute a relação entre open design e fabricação digital com economias distribuídas. Argumenta-se que o open design e a fabricação digital têm o potencial de reduzir os impactos causados pelo setor de vestuário, mas enfatiza-se que ambas as estratégias, por si só, não conduzem a um cenário mais sustentável. 


\section{INTRODUCTION}

According to several authors (e.g. FLETCHER and GROSE 2011; NIINIMÄKI and HASSI 2011; HIRSCHER 2013b; HIRSCHER and FUAD-LUKE 2013), the clothing sector currently adopts approaches to sustainability which focus on specific and limited issues, without sufficiently questioning the current production system.

Although these contributions are important to reduce impacts, it is necessary to adopt systemic solutions (SANTOS 2009; PEREZ and SANTOS 2016). It is also important to consider not only the principles of the environmental dimension of sustainability, but also those of the socio-ethical and economic dimensions, in order to adopt a holistic approach to sustainability (VEZZOLI 2010; GWILT 2014).

Clark (2008) presents an approach with the potential to promote systemic changes in the clothing sector and reduce impacts on the three sustainability dimensions: distributed economies. According to the author, this is a global-local approach that can be leveraged by the internet, which allows users, producers and designers to be directly connected, making the production system more transparent and creating opportunities for collaboration among the various actors. Two strategies for adopting this approach are open design and digital manufacturing.

The term "open design" was first used in 1999 through the establishment of the Open Design Foundation (ABEL et al. 2011; INSTITUTO FABER-LUDENS 2012). Although the origin of the open design practice is much older than that, the concept itself emerged from the open source software movement (BALKA et al. 2009; TROXLER 2011; NEVES and ROSSI 2011; INSTITUTO FABER-LUDENS 2012).

Open Design Foundation defines open design as the "design whose creators allow its free distribution and documentation, as well as modifications and derivations" (OPEN DESIGN FOUNDATION 2000; ABEL et al. 2011; INSTITUTO FABER-LUDENS 2012, p. 27, our translation). Its main objective is to allow users to be involved in the development process. For this, open design projects provide "all the necessary information for anyone to be able to manufacture an object", which enables local and customized production (NEVES and ROSSI 2011; CABEZA et al. 2015, p. 9, our translation).

The materialization of open design products can occur through digital manufacturing technologies. The term "digital manufacturing" refers to processes that use computer controlled machines descended from the numerically controlled milling machine created in 1952 at the Massachusetts Institute of Technology (MIT)
(GERSHLENFELD 2012). Digital manufacturing technologies are computer numeric control (CNC) machines capable of interpreting $C A D$ files, translating them into coordinates for the object manufacturing (NEVES 2014).

Currently, digital manufacturing technology has been exploited for personal manufacturing. This reveals its potential for local on-demand production and for product customization, combining technology with artisanal production (BALKA et al. 2009; NEVES and ROSSI 2011; TROXLER 2011; ANDERSON 2012; GERSHENFELD 2012). As Gershenfeld (2012) points out, the goal "is not to make what you can buy in stores but to make what you cannot buy".

The aim of this article is to analyze the potential of digital manufacturing technologies and open design to achieve a distributed economy, based on parameters of the environmental, social and economic dimensions of Design for Sustainability. Through this analysis, we intend to identify the limits and possibilities of digital manufacturing and open design in relation to the principles of Design for Sustainability applied to the clothing sector.

The research method adopted was qualitative and exploratory basic research, whose delineation was the bibliographic review. We consulted books, journal articles, conference proceedings, technical reports, theses and dissertations that addressed clothing sector, design for sustainability, distributed economies, open design and/ or digital manufacturing. We also carried out a systematic search on the "Portal de Periódicos da CAPES" database.

\section{DISTRIBUTED ECONOMIES}

\subsection{The distributed economies concept}

According to Vezzoli (2012, p. 41, our translation), several authors point out distributed economies as a "favorable economic model to unite the ethical-social dimensions with the environmental dimensions of sustainability". The LeNSin project $(2016$, p. 5) defines distributed economies as follows:

small-scale production units (structure), at or near the point of use, where the users are the producers - whether individuals, small businesses and/or local communities. These production units could be standalone or could be connected to each other through a network to share various forms of resources (physical and/ or knowledge-based ones; e.g. to share the energy surplus). 
A distributed economic system differs from centralized and decentralized systems (Figure 1). The centralized system is characterized by large productive units that deliver their products through large distribution networks, usually distant from the point of use. The decentralized system is composed of small production units that deliver their goods to users (LeNSin, 2016).

Figure 01 - Centralized, decentralized and distributed systems

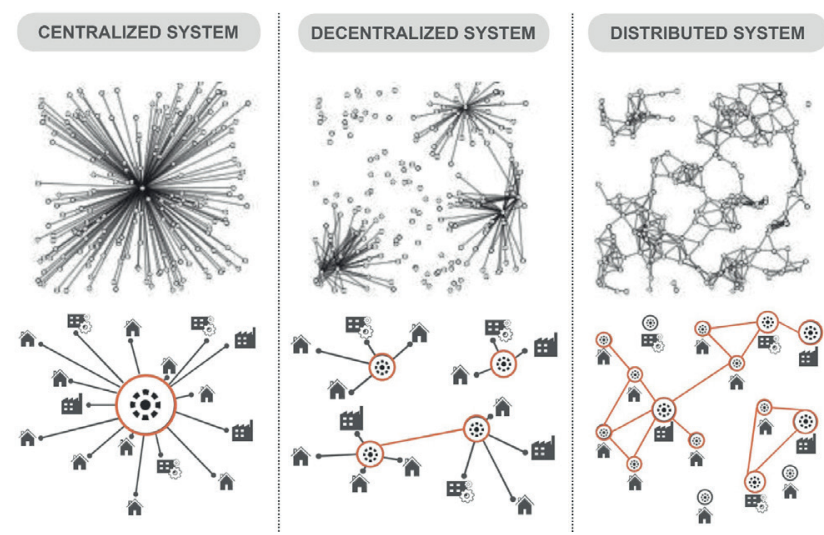

Source: adapted from LeNSin (2016) and Menichinelli (2016)

The model currently adopted in the fashion industry is centralized, as it is composed of large-scale production units and large distribution networks with global reach. This model is characterized by fast fashion, which focuses on the low cost of production and strategies of constantly updating the apparel design (SALCEDO 2014; TANJ 2016). To ensure the low cost, production is large-scale and displaced from the consumption points and the regions where products are designed (RISSARDI 2015, TANJ 2016). This centralized economic model has several impacts, pointed out by Johansson et al. (2005) and Vezzoli (2012):

- transport over long distances;

- distance between consumers and producers, causing consumers to be unaware of the environmental and social impacts of production, while producers face difficulties in meeting the true needs of consumers;

- vulnerability and inflexibility to respond to a rapid demand for change;

- outsourcing to countries with low production costs;

- compromised quality to keep prices low;

- diversity limitation of regional economic activities;

- weakening of local cultural identities.

The productive system of the fast fashion model presents all these characteristics, which shows the need for distributed approaches for the clothing sector. Based on the literature review, it is possible to relate the direct benefits of this model to some of the design for sustainability principles (Table 1).

Table 01: Distributed economy contributions to sustainability

\begin{tabular}{|c|c|}
\hline $\begin{array}{l}\text { DESIGN FOR SUSTAINTABILITY } \\
\text { PRINCIPLES }\end{array}$ & $\begin{array}{l}\text { DISTRIBUTED ECONOMIES } \\
\text { BENEFITS }\end{array}$ \\
\hline \multicolumn{2}{|c|}{ ENVIRONMENTAL DIMENSION } \\
\hline Minimizing resource use & $\begin{array}{l}\text { Reduces transport between the } \\
\text { production sites and the point } \\
\text { of use of the product }\end{array}$ \\
\hline Optimizing product lifespan & $\begin{array}{c}\text { Prioritizes quality over produc- } \\
\text { tive efficiency }\end{array}$ \\
\hline \multicolumn{2}{|c|}{ SOCIO-ETHICAL DIMENSION } \\
\hline Improving working conditions & $\begin{array}{c}\text { Approaches different actors, } \\
\text { favoring the supervision of } \\
\text { working conditions. }\end{array}$ \\
\hline $\begin{array}{l}\text { Increasing equity and fairness in } \\
\text { relation to actors }\end{array}$ & $\begin{array}{c}\text { Allows local community to have } \\
\text { greater power over productive } \\
\text { means }\end{array}$ \\
\hline $\begin{array}{l}\text { Empowering / promoting } \\
\text { sustainable and responsible } \\
\text { consumption }\end{array}$ & $\begin{array}{l}\text { Opens the processes of innova- } \\
\text { tion and product development } \\
\text { for the participation of external } \\
\text { actors, allowing individuals to } \\
\text { become aware of social and } \\
\text { environmental issues. }\end{array}$ \\
\hline Promoting social cohesion & $\begin{array}{l}\text { Provides collaboration between } \\
\text { actors }\end{array}$ \\
\hline $\begin{array}{c}\text { Strengthening / valuing local } \\
\text { resources }\end{array}$ & $\begin{array}{c}\text { Uses and values local resources, } \\
\text { both human and cultural }\end{array}$ \\
\hline \multicolumn{2}{|c|}{ ECONOMIC DIMENSION } \\
\hline $\begin{array}{c}\text { Strengthening and valuing local } \\
\text { material resources }\end{array}$ & $\begin{array}{c}\text { Uses and enhances local materi- } \\
\text { al resources }\end{array}$ \\
\hline Valuing waste reintegration & Allows the use of local waste \\
\hline $\begin{array}{l}\text { Respecting and valuing local } \\
\text { culture }\end{array}$ & Promotes diversity \\
\hline Promoting network organization & $\begin{array}{c}\text { Allows local productive units to } \\
\text { network with each other }\end{array}$ \\
\hline Promoting local economy & $\begin{array}{c}\text { Promotes local small-scale } \\
\text { production }\end{array}$ \\
\hline Being competitive & $\begin{array}{l}\text { Allows greater flexibility to } \\
\text { respond to a rapid demand for } \\
\text { change }\end{array}$ \\
\hline
\end{tabular}

Source: based on Johansson et al. (2005), Clark (2008), Manzini and Vezzoli (2008), Vezzoli (2010, 2012), Ertekin and Atik (2015)

The LeNSin project (2016) presents a classification of distributed economies, we highlight, for this publication, 
Distributed Production of products (DP) and Distributed Design (DD), which are discussed below.

\subsection{Distributed design and distributed production}

The LeNSin project $(2016$, p. 8) defines a distributed design system as "an open design project where small-scale design units (e.g. one person/computer), whether individuals, small businesses and/or local communities, are connected with others". According to the project, open innovation, crowd-design and open design approaches are related to distributed design.

There is no consensus about the relationship between open design, open innovation and crowd-design (ESTELLÉS-AROLAS and GONZÁLEZ-LADRÓN-DEGUEVARA 2012). In this work, crowd-design is considered as an open innovation modality, more specifically distributed co-creation, based on Avital (2011), Bauwens et al. (2012), Trentini et al. (2012), Mesacasa, Kistmann and Schmid (2015). Crowd-design may or may not be related to open design.

The central idea of distributed design is that a number of networked actors can participate in the product development process. This connection is driven by the development and popularization of the internet and communication technologies, which allows the rapid sharing of ideas and design blueprints (TROXLER 2011; MENICHINELLI 2016).

From the perspective of open design, Kostakis et al. $(2015,2016)$ propose the concept of "design global, manufacture local", which refers to processes in which design is developed globally, through sharing and improving ideas and design blueprints, while the manufacturing processes occur locally.

Open design, therefore, is a distributed design approach that can favor distributed production. Avital (2011) reinforces this. According to him, the users, geographically distributed, are the main actors, because they engage in manufacturing of open design artifacts.

A distributed production system is defined by the LeNSin project $(2016$, p. 7$)$ as follows: "small-scale production units, at or near the point of use, where the users are the producers - whether individuals, small businesses and/or a local community."

According to Kohtala (2015), distributed production represents a change in consumption and production patterns. In this approach, users have a greater ability to affect what is produced, either through personalization or through personal manufacturing (KOHTALA 2015; RAUCH et al. 2016).

One of the distributed production characteristics most emphasized by researchers is the possibility for the user to personalize the products by digital means and to influence what is produced, characteristics that indicate an approximation between distributed production and co-creation (Ibidem). Therefore, open design is an approach that can be related to both distributed design and production.

One approach to distributed production is the use of digital manufacturing technologies, which facilitate on-demand production (KOSTAKIS et al. 2015, 2016; RAUCH et al. 2016). It is understood that open design and digital manufacturing technologies are strategies that can complement each other when open design blueprints are used to materialize artifacts through digital manufacturing in a distributed production context (NEVES and ROSSI 2011; CABEZA et al. 2014, 2015). Figure 2 summarizes the relationship proposed by this paper between open design and other approaches of distributed design and between open design and distributed production, with emphasis on digital manufacturing strategies.

Figure 02 - Relationship between open design and digital manufacuring with $D D$ and $D P$

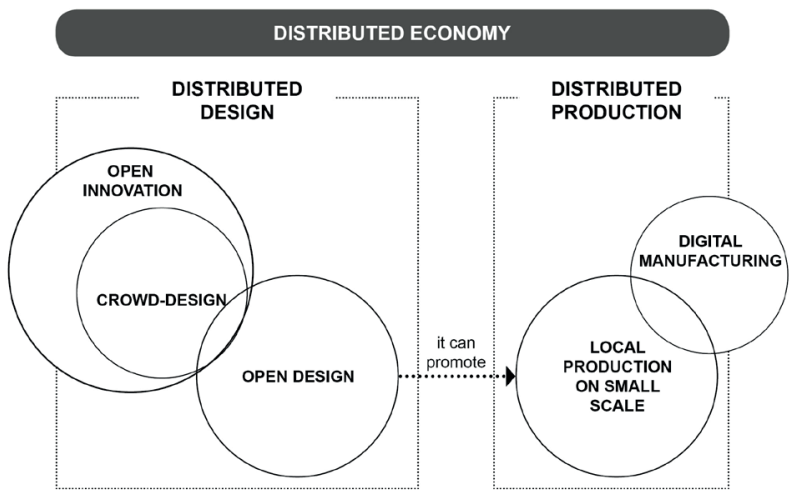

Source: Own (2017)

The goal of design blueprints sharing, in open design, is the artifact production, which occurs locally in a distributed way, feature that can be enhanced by the use of digital manufacturing technologies (BALKA et al. 2009; AVITAL 2011, BAUWENS et al., 2012; INSTITUTO FABERLUDENS 2012). As Gershenfeld (2012) reinforces, it is the ability to globally distribute digital project files and then manufacture products locally, on demand, using digital manufacturing technologies, that brings revolutionary implications for the industry.

\section{OPEN DESIGN IMPLICATIONS FOR SUSTAINABILITY}

A question pointed by most of the consulted authors (e.g. NIINIMÄKI and HASSI 2011; INSTITUTO FABER-LUDENS 
2012; HIRSCHER 2013; HIRSCHER and FUAD-LUKE 2013; FERRONATO and FRANZATO 2015; HIRSCHER and NORONHA 2015; KOHTALA 2015) is the possibility of extending the product life cycle due to the emotional connection that the user establishes with the artifact when it is customized or when the user is involved with its development process.

Some authors (e.g. NIINIMÄKI and HASSI 2011; KOHTALA 2015; STRIEN and PONT, 2016) also argue that adopting a modular design approach, together with open design, contributes to the extension of the product life cycle because it facilitates their disassembly, allowing parts to be changed when worn or when the user wants to modify the clothing.

However, there is no way to be sure whether open design actually extends the product life cycle and consequently reduces consumption (NIINIMÄKI and HASSI 2011; KOHTALA 2015). If the user does not have good experience with the development process, if there is a failure in the clothing production or if the process is very complicated, there is a possibility that the effect is the opposite and the product will have a reduced life cycle (HIRSCHER 2013).

If, in fact, open design provides emotional connection between users and their products, this may actually have side effects. This may compromise the adoption of intensified product use strategies such as sharing and reuse (KOHTALA 2015).

Another issue is the possibility of an unsustainable proliferation of artifacts due to the democratization of design and production processes (RICHARDSON 2015). Open design, therefore, does not imply in itself a decrease in environmental impact. Therefore, it is necessary to consider the design for sustainability principles from the planning of an open design project, in order to help users to behave more sustainably (NIINIMÄKI and HASSI 2011; THACKARA 2011; RICHARDSON 2015).

Regarding this last point, it is important to consider that, if the garment is manufactured by the users themselves, they will have control over this stage and its impacts, which include the selection of materials, cutting and reuse of waste. To assist the user, one can plan the product and its instructions in order to reduce possible impacts and guide the user in the decision-making process.

Although some issues need attention, open design as a distributed economy strategy can present the same benefits to sustainability of this approach. Furthermore, as the design process is documented and disseminated, as well as design blueprints, open design also enables more sustainable solutions to be improved or replicated by others, increasing their potential for impact mitigation (KOSTAKIS et al. 2015).

\section{DIGITAL MANUFACTURING IMPLICATIONS FOR SUSTAINABILITY}

Digital manufacturing technologies allow an on demand production, eliminating possible leftover stock (NIINIMÄKI and HASSI 2011; STRIEN and PONT 2016). Anderson (2012) emphasizes that with these technologies, it is possible to produce single products or small lots without being overtaxed for exclusivity, since there is no need to re-adjust the manufacturing structure for this product. On the other hand, mass production is still favored by traditional technologies, which allow economies of scale (ANDERSON 2012; BARROS and SILVEIRA 2015).

However, some issues should be considered with regard to sustainability. Kohtala (2015) points out that personal production may lead to individuals becoming increasingly exposed to materials and processes whose toxicity is not yet known. She also points out that the production of new types of artifacts may compromise their suitability to current recycling systems.

Kohtala and Hyysalo (2015) add that sustainability is not a goal in itself in makerspaces. According to the authors, the most considered aspects currently are repair, reduction, reuse and recycling of materials, power supply, electricity consumption and more sustainable materials.

Users' commitment to sustainability, therefore, is a fundamental issue. Technological approaches have limited effectiveness to reducing impacts, as they need to be accompanied by behavioral changes to ensure the long-term sustainability of new technologies (RICHARDSON 2015).

Neves (2014, p. 49, our translation) emphasizes that digital manufacturing technologies can not be perceived as an end in itself. Their greatest potential is the creativity that is allowed to emerge. According to the author, "machines, when isolated, will continue to produce copies of what is already done in today's industry." It is therefore necessary to value the individuals behind the digital manufacturing and their use of it.

\section{CONCLUSION}

Distributed economies are an approach able to attain design for sustainability principles. It is relevant especially for the clothing sector, whose production system is centralized and presents several social and environmental impacts.

Open design and digital manufacturing, as argued in this paper, are distributed economy strategies related to 
distributed design and production that can be adopted by the clothing sector. They have the potential to reduce the impacts caused by this sector, but both strategies in themselves do not lead to a more sustainable scenario, since they can lead to rebound effect or have impacts not yet considered.

Therefore, it is necessary to consider and employ the design for sustainability principles from the beginning of an open design and digital manufacturing project, in order to explore all their potential to achieve environmental, socio-ethical and economic sustainability.

For future works, it will be of particular interest a practical research with the application of open design and digital manufacturing technologies to clothing development. This kind of research would be important to explore how to address design for sustainability principles into open design and digital manufacturing clothing projects.

\section{ACKNOWLEDGMENTS}

The research presented on this paper is supported by CAPES Foundation and is a result of a partnership with the LeNSin project, supported by ERASMUS+.

\section{REFERENCES}

ABEL, B. van; EVERS, L.; KLAASSEN, R. Preface. In: ABEL,

B. van Abel; Klaassen, R.; Evers, L.; Troxler, P. (Eds.). Open Design Now: Why Design Cannot Remain Exclusive. Amsterdam, BIS publishers, 2011. Avaiable at: <http:// opendesignnow.org/index.html?p=38.html>. Acessed 19 November. 2016.

ANDERSON, C. Makers: a nova revolução industrial. Translated by SERRA, A. C. C. Rio de Janeiro, Elsevier, 2012. Original title: Makers - the new industrial revolution.

AVITAL, M. The generative bedrock of open design. In: ABEL, B. van; KLAASSEN, Roel; EVERS, Lucas; TROXLER, Peter (Eds.). Open Design Now: why design cannot remain exclusive. Amsterdam, BIS publishers, 2011. Available at: <http://opendesignnow.org/index.html?p=405.html>. Acessed 19 November 2017.

BALKA, K.; RAASCH, C.; HERSTATT, C. Open source enters the world of atoms: a statistical analysis of open design. First Monday, 14 (11), 2009.

BARROS, A. M. DE; SILVEIRA, N. S. A FÁBRICA MÍNIMA: tecnologias digitais para a produção local e customizada de artefatos físicos. Estudos em Design, Rio de Janeiro, 23 (1), pp. 61-73, 2015.
BAUWENS, M. et al. Synthetic overview of the collaborative economy. Amsterdam, P2P Foundation, 2012. Technical report.

CABEZA, E. U. R; MOURA, M.; ROSSI, D. Design aberto: prática projetual para a transformação social. Strategic Design Research Journal, São Leopoldo, 7(2), pp. 56-65, 2014.

CABEZA, E. U. R.; ROSSI, D. C.; MOURA, M. Ecossistema Open Design. In: CONFERENCE ON INTEGRATION OF DESIGN, ENGINEERING AND MANAGEMENT FOR INNOVATION, 4., 2015, Florianópolis.

CLARK, H. Slow + fashion - an oxymoron - or a promise for the future...? Fashion Theory, 12(4), pp. 427-446, 2008.

ERTEKIN, Z. O.; ATIK, D. Sustainable Markets: Motivating Factors, Barriers, and Remedies for Mobilization of Slow Fashion. Journal of Macromarketing, 1(1), pp. 53-69, 2015.

ESTELLÉS-AROLAS， E.; GONZÁLEZ-LADRÓN-DEGUEVARA, F. Towards an integrated crowdsourcing definition. Journal of Information Science, 38(2), pp. 189-200, 2012.

FERRONATO, P. B.; FRANZATO, C. Open Design e Slow Fashion para a Sustentabilidade do Sistema Moda. Modapalavra E-periódico, Florianópolis, year 9, special edition, pp. 104-115, 2015.

FLETCHER, K.; GROSE, L. Moda \& sustentabilidade: design para a mudança. Translated by MARCOANTONIO, Janaína. São Paulo, Editora Senac São Paulo, 2011. Original title: Fashion \& sustainability: design for change.

GERSHENFELD, N. How to Make Almost Anything: The Digital Fabrication Revolution. Foreign Affairs, Tampa, November/December 2012. Available at: <https:// www.foreignaffairs.com/articles/2012-09-27/how-makealmost-anything >. Acessed 19 November 2016.

GWILT, A. Moda sustentável: um guia prático. Translated by LONGARÇO, M. São Paulo, Gustavo Gili, 2014 Original title: A practical guide to sustainable fashion.

HIRSCHER, A.-L. Fashion Activism Evaluation and Application of Fashion Activism Strategies to 
Ease Transition Towards Sustainable Consumption Behaviour. Research Journal of Textile and Apparel, 17(1), pp. 23-38, 2013.

FUAD-LUKE, Alastair. Open participatory designing for an alternative fashion economy. In: NIINIMÄKI, K. (Ed.). Sustainable fashion: new approaches. Helsinki, Aalto University, 2013. pp. 174-197.

; NORONHA, J. V. Open Ends: on Chance and Attachment in Clothing Design. In: MAKING RESEARCH, RESEARCH MAKING CONFERENCE, 2015, Aarhus, Dinamarca.

INSTITUTO FABER-LUDENS. Design Livre. São Paulo, Clube dos Autores, 2012.

JOHANSSON, A.; KISCH, P.; MIRATA, M. Distributed economies - A new engine for innovation. Journal of Cleaner Production, 13(10-11), pp. 971-979, 2005.

$\mathrm{KOHTALA}, \mathrm{C}$. Addressing sustainability in research on distributed production: An integrated literature review. Journal of Cleaner Production, 106, pp. 654-668, 2015.

HYYSALO, S. Anticipated environmental sustainability of personal fabrication. Journal of Cleaner Production, 99, pp. 333-344, 2015.

KOSTAKIS, Vasilis; NIAROS, Vasilis; DAFERMOS, George; BAUWENS, Michel. Design global, manufacture local: Exploring the contours of an emerging productive model. Futures, 73, pp. 126-135, 2015.

KOSTAKIS, Vasilis; LATOUFIS, Kostas; LIAROKAPIS, Minas; BAUWENS, Michel. The convergence of digital commons with local manufacturing from a degrowth perspective: two illustrative cases. Journal of Cleaner Production, in press, pp. 1-10, 2016.

LeNSin - INTERNATIONAL LEARNING NETWORK ON SUSTAINABILITY. The LeNSin research hypothesis: the design of S.PSS applied to DE: win-win offer model for a sustainable development for all. Milan, Politecnico di Milano - Design dept, 2016. Reserach report.

MENICHINELLI, M. A framework for understanding the possible intersections of design with open,
P2P, diffuse, distributed and decentralized systems. Disegno - The Journal of Design Culture, 3( 1-2), pp. 4471, 2016.

MESACASA, A.; KISTMANN, V. S. DE C. B.; SCHMID, A. L. Inovação aberta como possibilidade de diversificação de agentes de cooperação junto aos processos de inovação na indústria do vestuário. Modapalavra E-periódico, Florianópolis, 8(16), pp. 145-162, 2015.

NEVES, H.; ROSSI, D. Open Design. In: CONGRESSO BRASILEIRO DE GESTÃO DE DESENVOLVIMENTO DE PRODUTO, 8, 2011, Porto Alegre.

NEVES, H. Maker Innovation: do Open Design e Fab Labs ... às estratégias inspiradas no movimento Maker. 261 pages. Thesis (PhD in Architecture and Urbanism) Faculdade de Arquitetura e Urbanismo, Universidade de São Paulo, 2014.

NIINIMÄKI, K.; HASSI, L. Emerging design strategies in sustainable production and consumption of textiles and clothing. Journal of Cleaner Production, 19(16), pp. 1876-1883, 2011.

OPEN DESIGN FOUNDATION. The Open Design

Definition. V. 0.2. 2000. Available at: <http://www. opendesign.org/odd.html>. Acessed 06 February 2017.

PEREZ, I.; SANTOS, A. Lacunas de pesquisa em design de moda para a sustentabilidade em sua dimensão ambiental. In: CONGRESSO BRASILEIRO DE PESQUISA E DESENVOLVIMENTO EM DESIGN, 12., 2016, Belo Horizonte. Blucher Design Proceedings. São Paulo: Editora Blucher, 2016. pp. 1987-1998.

RAUCH, E.; DALLASEGA, P.; MATT, D. T. Sustainable production in emerging markets through Distributed Manufacturing Systems (DMS). Journal of Cleaner Production, 135, pp. 127-138, 2016.

RICHARDSON, M. Pre-hacked: Open Design and the democratisation of product development. New Media and Society, 18(4), pp. 653-666, 2015.

RISSARDI, L. O poder da moda: cenários, desafios e perspectivas. São Paulo, Associação Brasileira da Indústria Têxtil e de Confecção, 2015. Technical report. 
SALCEDO, E. Moda ética para um future sustentável. Translated by FRACALOSSI, Denis. São Paulo, Gustavo Gili, 2014. Original title: Moda ética para un futuro sostenible.

SANTOS, A. Níveis de maturidade do design sustentável na dimensão ambiental. In: MORAES, Dijon de; KRUCKEN, Lia (Org.). Design e sustentabilidade. Barbacena, EdUEMG, pp. 13-26, 2009.

STRIEN, M. Van; PONT, V. de. Open Source Fashion Manifesto. Rotterdam, Het Nieuwe Instituut, 2016.

TANJI, T. Escravos da moda: os bastidores nada bonitos da indústria fashion. Galileu, 23 June 2016. Available at: $\quad<$ http://revistagalileu.globo.com/Revista/noticia/2016/06/escravos-da-moda-os-bastidores-nada-bonitos-da-industria-fashion.html>. Acessed 15 February 2017.

THACKARA, J. Into the open. In: ABEL, B. van Abel; Klaassen, R.; Evers, L.; Troxler, P. (Eds.). Open Design Now: Why Design Cannot Remain Exclusive. Amsterdam, BIS publishers, 2011. Available at: <http://opendesignnow. org/index.html?p=403.html $>$. Acessed 19 November 2016.

TRENTINI, A.; FURTADO, I.; DERGINT, Dario Eduardo Amaral; REIS, Dalcio Roberto dos; CARVALHO, Helio Gomes. Inovação Aberta e Inovação Distribuída, Modelos Diferentes de Inovação? Open Innovation and Distributed Innovation Differents Models of Innovation? Estratégia \& Negócios, Florianópolis, 5(1), pp. 88-109, 2012.

TROXLER, P. Libraries of the Peer Production Era. In: ABEL, B. van Abel; Klaassen, R.; Evers, L.; Troxler, P. (Eds.). Open Design Now: Why Design Cannot Remain Exclusive. Amsterdam, BIS publishers, 2011. Available at: <http:// opendesignnow.org/index.html? $\mathrm{p}=411 . \mathrm{html}>$. Acessed 19 November 2016.

VEZZOLI, C. Design de sistemas para a sustentabilidade: teoria, métodos e ferramentas para o design sustentável de "sistemas de satisfação". Translated by: REGO, M. A. Salvador, EDUFBA, 2010.

Design e sistema de inovação para a sustentabilidade. In: DE CARLI, Ana Mery Sehbe; VENZON, Bernardete Lenita Susin (Org.). Moda, sustentabilidade e emergências. Caxias do Sul, Educs, pp. 23-66, 2012. 